\title{
Technology and sustainability for the development of the Caldenal
}

\author{
H. E. Laborde, R. E. Brevedan \& M. N. Fioretti \\ Departamento de Agronomía, \\ Universidad Nacional del Sur and CERZOS, CONICET, Argentina
}

\begin{abstract}
The Caldenal is a temperate semi-arid region located in the central part of Argentina and comprises an area of about $40,000 \mathrm{~km}^{2}$. It is located in the ecotone between the cultivated humid Pampa to the east and the arid Monte to the west.

The region is characterized by a highly variable annual and seasonal distribution of rainfall $(400-600 \mathrm{~mm})$ concentrated in spring and fall. Average annual potential evapotranspiration is $800 \mathrm{~mm}$. The average annual temperature is $15-16^{\circ} \mathrm{C}$. Soils are mainly Calciustolls with a petrocalcic horizon at a depth varying from 0.5 to $2 \mathrm{~m}$.

Cattle raising, based on cow-calf operations, is the most important economic activity in the Caldenal where stocker calves are raised to be fattened later in the more humid Pampa. The ranchers in Caldenal practice continuous grazing with very high grazing pressure, that has resulted in a severe overgrazing. Stocking

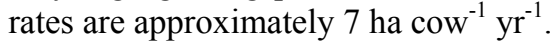

Currently the area supports an increasing pressure over its grass herbaceous resources. On the other hand, the humid Pampa is increasingly devoted to cash crop cultivation, mainly soybean. This causes a displacement of cattle breeding and fattening enterprises to more marginal areas. As a result, some feed-lot businesses are being located in the Caldenal region nowadays.

The Caldenal region appears suitable for a more intensive agricultural use. In an attempt to find a cropping strategy that reduces the constraints of climate and soil a non-tillage, legume ley farming system based on improved high-yielding pasture legumes is proposed in the Caldenal.
\end{abstract}

Keywords: Caldenal, rangeland, livestock production, medics, ley farming. 


\section{Introduction}

The Caldenal region included in the rangeland area of Argentina occupies about $40,000 \mathrm{~km}^{2}$ between approximately $32^{\circ}$ and $40^{\circ} \mathrm{S}$ latitude. The region is a transition between the Monte desert to the west and the cultivated humid Pampa to the east. The Caldenal is part of the semiarid central Pampa ecoregion [1]. The humid Pampa is increasingly devoted to cash crop cultivation, mainly soybean, wheat and corn. This causes a displacement of cattle breeding and fattening enterprises to more marginal areas where non-irrigated crops are not possible. So far, the grassland ecosystem of the Caldenal is devoted to cow-calf enterprises (approximately $7 \mathrm{ha} \mathrm{cow}^{-1} \mathrm{yr}^{-1}$ ) where stocker calves are raised and then exported to be fattened in the more humid Pampa. The Caldenal along other semiarid regions of Argentina is expected to receive, in the near future, a large pressure to use its natural resources for breeding cattle.

While a system of extensive animal production is widespread in the Caldenal and has persisted for 100 years or so, its profitability has often been marginal depending on the size of the enterprise. The sustainability of this system is now being questioned, given the increased capital expenditure required. Attempts to replicate the cash crop system common in the humid Pampa have been done in the Caldenal. In fact, some feed-lot businesses are being located in the region nowadays.

The eastern part of the Caldenal is at the fringe of the arable humid and subhumid Pampa. Plowing of this marginal land for crops (wheat or oat) is a permanent temptation for land owners. Most of the time this is translated into poor grain crop, leaving behind an impoverished ecosystem in terms of forage plant quality and soil erosion.

The climate of the region poses constraints to agriculture. Low and erratic rainfall, severe cold or high temperature, resulting in high season-to-season variability. In dry areas, measures to utilize natural precipitation more efficiently in situ must have high priority, since this will not only help to increase production and decrease risk, but also help to reduce erosion.

Land degradation problems have also emerged and include soil salinization and compactation. When soil is lost from fields it disrupts water courses and damage natural resources.

Overgrazing led not only to changes in the vegetation but also in the structure of the soils. There is an increase in bulk density and a reduction in depth of the top soil horizon of the grazed areas. The negative effect of grazing on the physical properties of soil can be observed down to a depth of $0.10 \mathrm{~m}$. The water retention of grazed and ungrazed areas reflect the changes in pore spaces distribution. Total porosity in the top few centimeters are lower in grazed than in ungrazed areas $(17 \%)$ due to the collapse of large pores. There is a marked reduction in the quantity and density of roots in the top soil horizon and there are also changes in the mean diameter of roots [2].

Water conservation and erosion control are central to dry farming objectives. Significant advances have been made in water conservation techniques through 
improved methods of weed control, surface residue management and minimum tillage practices.

Wind erosion is almost always associated with cultural practices that leave the soil unprotected when high winds occur. Most control practices are based on establishing adequate surface cover and by maintaining a rough soil surface. Water erosion is much less of a problem than wind erosion.

Many semiarid zones are now being severely overused. The tendency is for individuals to over-use and under-invest in them. As a consequence many rangelands are degrading rapidly. Dryland degradation is a widespread phenomena which affects grazing lands around the world. To help prevent further over-utilization and degradation the vegetation and land must be used within its capability to support grazing and dryland agriculture.

Forage from natural rangeland provides a major component of the animal feed resources in the Caldenal. However, pressure from the increasing animal populations has led to over-stocking and over-grazing. One solution to these problems is to improve the productivity of the natural rangeland. The strategies for the development of natural rangeland like the Caldenal should include: the appropriate distribution of water points as a mean of control of grazing activities, the establishment of feed reserves to be utilized during the period where vegetation is scarce, the establishment of range reserves on order to secure an abundance of fodders during the critical periods and the appropriate fencing of too large paddocks.

The Caldenal region appears suitable for a more intensive agricultural use. For instance, alfalfa crop for hay and livestock feeding could be successfully cultivated using some kind of irrigation. Water could be derived from rivers but besides the Colorado River the only surface water is what drains from rainfall forming lagoons and salt pans in some depressions. Shallow ground-water is the main source of water in the region but its quality is poor, the conductivity ranges from 0.74 to $16.00 \mathrm{dS} \mathrm{m}^{-1}$. The high salinity content of ground water is mainly a consequence of overgrazing and deforestation [3].

Viglizzo et al. [1] suggested that land use is the principal factor driving the environmental behavior of a region. In the Caldenal contamination or erosion risk indicators are particularly sensitive to land use. Also agriculture has had a negative impact on natural habitats, wildlife and biological diversity.

Minimum tillage or non-tillage practices compensate in part the more intensive use of the land. Such practices can determine an increased productivity without increasing the soil erosion risk [1].

\section{Dryland farming in the Caldenal}

In an attempt to find a cropping strategy that reduces the limitations of climate and soil it is proposed a non-tillage, legume ley farming system based on improved high-yielding pasture legumes in the Caldenal. The key feature of the system is the use of biologically fixed $\mathrm{N}$, minimal soil disturbance with mulch cover, self-regenerating legume ley pastures, and integration of cropping with a livestock grazing enterprise. There is a rotation in which legume pastures grazed by sheep and cattle are alternated with a cropping phase. 
The system is a highly flexible low input agriculture which permits a wide range of different grain and pasture/animal options according to the duration of the ley and cropping phases. There is now overwhelming evidence to show the advantages of this ley farming system over the wheat-fallow agriculture which is supplanted in terms of productivity and the preservation of soil resources. However it should be recognized that is the legume pasture, not the animal which makes the main contribution to increased wheat yield potential and the restoration of soil structure and fertility during the intercropping period, livestock being the most profitable way of converting the pasture forage to food and fiber. The use of pastures containing subterranean clover (Trifolium subterraneum) or annual medics (Medicago spp.) to improve soil nitrogen fertility for following crops was considered to be a successful model of sustainability and profitability in Australia. However, since the 1970s there has been a trend towards shorter pasture-crop rotations and continuous cropping in many parts of southern Australia. This in part reflects the relative economic returns from livestock enterprises and crop production, and the perceived shortcomings in the ley system associated with problems of pasture decline and soil acidification.

The availability of $\mathrm{N}$, more than any other mineral element, is a critical determinant of both the structure and productivity of grassland in plant communities. Besides, mineral $\mathrm{N}$ supplies to the plant community largely determine the value of the biomass produced as forage for consumers. Most efforts aimed at improvement of rangeland under the assumption that animals fed on nitrogen-rich forage such as legumes increase their consumption of ligneous vegetation.

Legume crops increase land use, permitted alternative weed control and reduce the amount of fertilizers used. Because of their ability to fix atmospheric nitrogen, can be important in nutrient cycling and soil development processes on $\mathrm{N}$-poor soils. Improved fertility provided by the legume would increase wateruse efficiency.

In that situation legumes might be expected to have a significant role. In terms of their ability to exploit stored soil moisture, legumes are unlikely to fare very well in competition with grasses. Legumes seldom dominate natural ecosystems.

Pasture legumes are considered in light of their agricultural contributions to increase livestock production, to fix $\mathrm{N}$ from the atmosphere leading to an increase in soil $\mathrm{N}$ and improvement in soil structure, to increase the availability of some nutrients other than $\mathrm{N}$ and raise the cation exchange capacity by increasing the levels of organic matter [4]. The wider use of pasture legumes is seen as the most viable option for increasing crop yields in dryland areas, such as the Caldenal.

Management studies must define the critical range of grazing pressure beyond which persistence is threatened. Persistence is sensitive to both undergrazing and over-grazing. On the other hand management of diversity is more complex and more species can increase production costs on the farm. 
What is needed is a good understanding of the ecophysiological requirements of targeted habitats and a knowledge of what species likely to fit these habitats will be found.

Alfalfa fixes more $\mathrm{N}$ than medics even under drought conditions. However the shallow soils and the shortage of rain in the Caldenal are not suitable for alfalfa except in lowlands close to rivers or streams. Medics have strategies to avoid drought and produce forage and plenty of seeds in those environments.

Medic pastures with proper grazing management regenerate from their own seed in subsequent seasons, even after a cereal crop has been grown on the same land.

Medicago minima (L) Bartal. var. minima is an annual legume species that was introduced from Europe and became naturalized in the Caldenal. During spring, this species can be an important forage resource for cattle in the extensive over-grazed areas of this region. Under these conditions, M. minima can constitute more than $60 \%$ of the total herbaceous production. This is in contrast to most rangelands which suffer a scarcity of natural leguminous species [5].

That annual legume is common in several other arid and semiarid rangelands and can become a dominant species under conditions of aridity and over-grazing [6].

Initiation of its cycle occurred in autumn and appeared to be associated with soil water availability. The end of the growing season happened during late spring, concomitant with high maximum air temperatures.

The species hasten its development when air temperature increases and soil water availability decreases. This could be an important strategy in the species which allows them to persist as seeds, and produce a new generation under favorable environmental conditions [7]. M. minima shows a high phenotypic plasticity under different levels of soil water availability which may enhance its capacity to survive and reproduce. It can survive under severe drought conditions and exploit the environmental resources when they are available. Their persistence in the region appears to be ensured by their capacity to colonize open, degraded areas as well as to grow in association with perennial grasses [8]. When exposed to water stress allocated a higher proportion of the total plant dry weight to fruits than those grown under irrigated conditions during early spring. Under drought conditions this is a beneficial feature because it enables plants to complete their life cycle and ensure seed production [8].

Plants survived even those exposed repeatedly to very severe water stress (-6.0 MPa or less) [9].

Medics showed a fairly good dry matter production (Table 1) mostly in winter time, in spite that Caldenal has not a strictly Mediterranean climate [10]. In vitro dry matter digestibility is over $70 \%$ during winter (Table 1) [11].

Associations of oat and legumes are frequently utilized in the semiarid regions of Argentina to extend forage production from autumn to late spring season. Dry matter yield of those associations are shown in Table 2.

Weeping lovegrass and other warm season forage grasses were introduced in the Caldenal to improve forage production. There was an increase in dry matter yield of those grasses when sown with alfalfa compared with the grass alone, and 
also an increase in the wheat grain yield sown after the pasture (Table 3). These results show the good potential to get higher forage and subsequent grain yields with grass-legume mixtures compared with grass pastures alone.

Table 1: $\quad$ Dry matter (DM) and digestible dry matter (DDM) yield (in $\mathrm{Mg}$ $\mathrm{ha}^{-1}$ ) of annual medics (Medicago spp) and vetch (Vicia sativa). Two-year average, SW Buenos Aires province.

\begin{tabular}{|c|c|c|c|c|c|}
\hline \multirow[b]{2}{*}{ Species } & \multicolumn{4}{|c|}{ DM } & \multirow{2}{*}{$\begin{array}{l}\text { DDM } \\
\text { Total }\end{array}$} \\
\hline & Autumn & Winter & Spring & Total & \\
\hline $\begin{array}{l}\text { M. truncatula } \\
\text { cv Jemalong }\end{array}$ & & $4.823 \mathrm{a}$ & $1.555 \mathrm{a}$ & $6.378 \mathrm{a}$ & $4.520 \mathrm{a}$ \\
\hline $\begin{array}{l}\text { M. truncatula } \\
\text { cv. Cyprus }\end{array}$ & 0.658 & $4.958 \mathrm{a}$ & $0.625 \mathrm{c}$ & $5.583 \mathrm{ab}$ & $4.120 \mathrm{a}$ \\
\hline $\begin{array}{l}\text { M. rugosa cv. } \\
\text { Paraponto }\end{array}$ & & $4.819 \mathrm{a}$ & & $5.477 \mathrm{ab}$ & $4.289 \mathrm{a}$ \\
\hline $\begin{array}{l}\text { M. littoralis } \\
\text { cv. Harbinger }\end{array}$ & & $4.507 \mathrm{ab}$ & $0.315 \mathrm{c}$ & $4.822 \mathrm{bc}$ & $3.670 \mathrm{ab}$ \\
\hline $\begin{array}{l}\text { M. rugosa cv. } \\
\text { Paragosa }\end{array}$ & & $3.727 \mathrm{~b}$ & $0.997 \mathrm{~b}$ & $4.724 \mathrm{bc}$ & $3.582 \mathrm{ab}$ \\
\hline $\begin{array}{l}\text { M. tornata } \\
\text { cv.Tornafield }\end{array}$ & 0.801 & $2.909 \mathrm{c}$ & $1.146 \mathrm{~b}$ & $4.055 \mathrm{c}$ & $3.070 \mathrm{~b}$ \\
\hline $\begin{array}{l}\text { Vicia sativa } \\
\text { cv. Common }\end{array}$ & & $2.587 \mathrm{c}$ & $0.495 \mathrm{c}$ & $3.883 \mathrm{c}$ & $3.041 \mathrm{~b}$ \\
\hline
\end{tabular}

Table 2: $\quad$ Dry matter (DM) yield of annual medics and vetch as pure stands or associated with oat. Two-year average, SW Buenos Aires province.

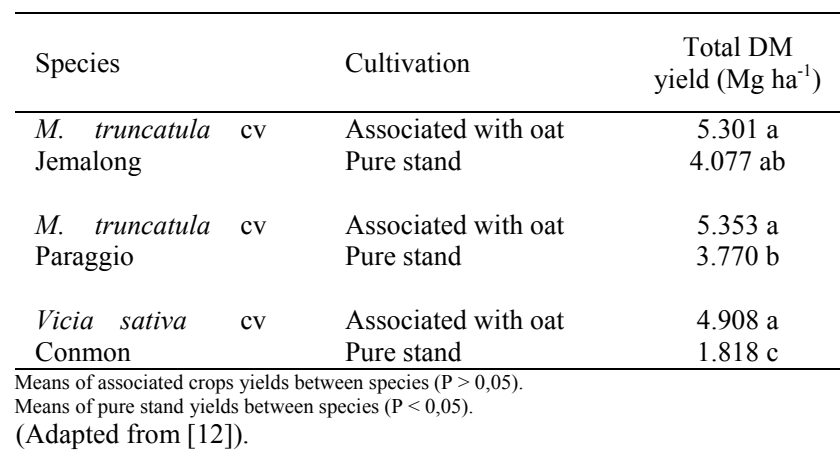


Table 3: $\quad$ Dry matter (DM) yield $\left(\mathrm{Mg} \mathrm{ha}^{-1}\right)$ of Digitaria eriantha, Eragrostis curvula and alfalfa as pure stands or associated and subsequent grain yield $\left(\mathrm{Mg} \mathrm{ha}^{-1}\right)$ of wheat. Three-year average, SW Buenos Aires province.

\begin{tabular}{lll}
\hline Treatments & DM & $\begin{array}{l}\text { Wheat } \\
\text { yield }\end{array}$ \\
\hline 1. Pure alfalfa & $4.880 \mathrm{ab}$ & $3.344 \mathrm{a}$ \\
2. Pure digitaria & $0.787 \mathrm{c}$ & $0.713 \mathrm{c}$ \\
3. Pure weeping lovegrass & $3.047 \mathrm{~b}$ & $0.639 \mathrm{c}$ \\
4. $1 \& 2$ seeded in different rows & $4.406 \mathrm{~b}$ & $2.127 \mathrm{ab}$ \\
$5.1 \& 3$ seeded in different rows & $6.601 \mathrm{a}$ & $1.659 \mathrm{~b}$ \\
$6.1 \& 2$ seeded in the same row & $5.042 \mathrm{ab}$ & $2.181 \mathrm{ab}$ \\
$7.1 \& 3$ seeded in the same row & $7.180 \mathrm{a}$ & $1.425 \mathrm{~b}$ \\
\hline
\end{tabular}

(Laborde et al., unpublished data).

The association of Digitaria eriantha with alfalfa increased the forage $(217 \%)$ and the subsequent wheat grain yield $(260 \%)$. In case of weeping lovegrass the increases were of 236 and $223 \%$, respectively.

In recent years, there has been a growing awareness world-wide of the general multipurpose value of forage trees and their specific role in croppinglivestock systems. However, farming of fodder shrubs is virtually unknown in the Caldenal. Species of Prosopis (P. flexuosa) are browsed regularly and play a significant role as a reserve and supplementary fodder [13].

\section{Conclusions}

Some areas crucial to dryland agriculture need to be understood before a great increase in agricultural productivity in the Caldenal could be achieved. For example, the livestock-cropping interface must be clarified. Farmers are not simply cash-crop producers or livestock producers-they are both. Decisions relating to one activity also have implications for the other. Secondly, risky production and risk attitudes are critical to dryland agriculture such as Caldenal's, particularly when producers are presented with new and uncertain technologies. Income stability may be as important as income levels and consequently, this affects production decisions regarding inputs, new techniques and even choices of farming activities. Finally, learning is a process that improves farmers' perceptions of available choices y consequently can reduce errors which farmers make when experimenting with these new technologies. If the farmer understands a new alternative better, he will be more likely to make a considered decision about it, with a greater chance of adopting it [14].

The development of more sustainable systems in the Caldenal can only be planned with the full involvement of communities who take them seriously, participate in the testing of options and take responsibility for the outcomes. 


\section{References}

[1] Viglizzo, E.F., A.J. Pordomingo, M.G. Castro and F.A. Lértora. 2002. La sustentabilidad ambiental del agro pampeano. INTA. $84 \mathrm{pp}$.

[2] Villamil, M.B., N.M. Amiotti and N. Peinemann. 2001. Soil degradation related to overgrazing in the semi-arid Southern Caldenal area of Argentina. Soil Sci., 166: 441-452.

[3] Paoloni, J.D., M.E. Sequeira, C.E. Fiorentino, N.M. Amiotti and R.J. Vázquez. 2003. Water resources in the semi-arid Pampa-Patagonia transitional region of Argentina. J. Arid Environments, 53: 257-270.

[4] Fitzpatrick, E.N. and I.C. Rowland. 1980. The role of legumes in dryland agriculture. Int. Congress Dryland Farming, Adelaide, Australia: 10-11.

[5] Fresnillo Fedorenko, D.E., O.A. Fernández and C.A. Busso. 1995. The effect of water stress on top and root growth in Medicago minima. J. Arid Environments, 29: 47-54.

[6] Volaire, F., M. Gordon and F. Lelievre. 1990. The natural herbaceous grasslands of Corsica. I. Construction of a typology by the characterization of both the environmental factors and the flora of the types. Agronomie, 10: 163-174.

[7] Fresnillo Fedorenko, D.E., O.A. Fernández, C.A. Busso and O.E. Elía. 1996. Phenology of Medicago minima and Erodium cicutarium in semiarid Argentina. J. Arid Environments, 33: 409-416.

[8] Busso, C.A., O.A. Fernández and D.E. Fresnillo Fedorenko. 1998. Dry weight production and partitioning in Medicago minima and Erodium cicutarium under water stress. Ann. Bot., 82: 217-227.

[9] Fresnillo Fedorenko, D.E. 1990. Estrategias ecológicas de Medicago minima (L.) Grufb. var. minima y Erodium cicutarium (L.) L'Herit., dos anuales de valor forrajero en el Caldenal. Ms. Tesis, Universidad Nacional del Sur, Argentina. 132 pp.

[10] Laborde, H.E., R.E. Brevedan and M.N. Fioretti. 1997. Sustainable development of the Caldenal region of central Argentina. En: J.L. Uso, C.A. Brebbia and H. Power (eds.). Ecosystems and Sustainable Development: 363-372.

[11] Gargano, A.O., F.E. Mockel, M.A. Adúriz and M.A. Cantamutto. 1986. Evaluación de leguminosas anuales del género Medicago comparadas con Vicia sativa. Rev. Arg. Prod. Anim., 6: 573-580.

[12] Gargano, A.O, M.A. Adúriz and M.C. Saldungaray. 1990. Rendimiento de forraje y semilla de Medicago truncatula cv Jemalong y cv Paraggio, y Vicia sativa. Rev. Arg. Prod. Anim., 10: 19-26.

[13] Campos, C.M. and R.A. Ojeda. 1997. Dispersal and germination of Prosopis flexuosa (Fabaceae) seeds by desert mammals in Argentina. J. Arid Environments, 35: 707-714.

[14] Nygaard, D.F. 1980. Socio-economic constraints to the future development of the dryland farming regions of the world. Int. Congress Dryland Farming, Adelaide, Australia: 39-40. 